\section{Research Square}

Preprints are preliminary reports that have not undergone peer review.

They should not be considered conclusive, used to inform clinical practice, or referenced by the media as validated information.

\title{
High Sensitivity C-reactive Protein Concentrations, Lipid Status And Duration Of Type-1 Diabetes
}

HAUWA BAKO ( $\sim$ bakohauwa@gmail.com )

Ahmadu Bello University Faculty of Medicine https://orcid.org/0000-0002-9684-945X

\section{Salisu Babura Mu'azu}

Rasheed Shekoni Specialist Hospital Jigawa State

Alkali Mohammed

Abubakar Tafawa Balewa University

Muhammmad Yalwa Gwarzo

Bayero University College of Health Sciences

Ibrahim Danjummai Gezawa

Bayero University College of Health Sciences

Mohammad Ahmad Bello

Bayero University College of Health Sciences

\section{Research article}

Keywords: Type 1 Diabetes, High Sensitivity C - reactive protein, Duration of Diabetes

Posted Date: March 4th, 2020

DOI: https://doi.org/10.21203/rs.3.rs-15946/v1

License: (c) (i) This work is licensed under a Creative Commons Attribution 4.0 International License.

Read Full License 


\section{Abstract}

Background: Low-grade inflammation, duration of diabetes, hyperglycemia, and dyslipidemia in the presence of other traditional risk factors have been implicated in the development of vascular, neurologic, musculoskeletal and dermatologic complications observed in type 1 diabetes irrespective of other confounding factors. The study was aimed at assessing the relationship between hs-CRP concentrations, lipid status and duration of type-1 diabetes.

Methods: Thirty-four patients aged 15-26 years comprising 14 females and 20 males diagnosed with type 1 diabetes $\leq 10$ years duration, who at first clinical assessment and thorough medical examination presented with any or a combination of the symptoms of ketoacidosis, polyuria, polydipsia, malnutrition, blurred vision, paresthesia, body swelling and frothy urine at the Accident and Emergency Unit of Rasheed Shekoni Specialist Hospital, Jigawa Nigeria were enrolled for the study in a cross-sectional pattern after granting informed consent or obtaining assent from parents or guardians. Blood samples for lipid profile, fasting plasma glucose (FPG) and High sensitivity $\mathrm{C}$ - reactive protein (hs-CRP) measurement were collected from all patients through venipuncture after 10 hours overnight fast for biochemical testing. Lipid profile and FPG were assayed using enzymatic methods, hs- CRP via Enzyme Linked immunosorbent Assay (ELISA) technique and Urinalysis with point of care urine test strips. Data obtained was analyzed and presented as Frequency, Percentages, Mean \pm SD and Pearson's correlation with statistical significance at $p \leq 0.05$.

Results: Patients biochemical characteristics were Fasting Plasma Glucose (9.86 \pm 4.44$)$, Total Cholesterol (4.77 \pm 2.07$)$, High Density Lipoprotein- Cholesterol (1.35 \pm 0.54$)$, Triglycerides $(2.17 \pm 1.06)$, Low Density Lipoprotein- Cholesterol (2.29 \pm 1.49$)$, hs-CRP (6.99 \pm 5.44$)$. Correlation matrix showed significant relationship between Triglycerides and hs-CRP $\left(r ; 0.378^{\star *}, p ; 0.005\right)$, Low Density LipoproteinCholesterol and hs-CRP $(r ; 0.457 *, p ; 0.007)$. hs- CRP concentrations in relation to duration of type-1 diabetes were $1-3$ years $(3.57 \pm 4.10), 3-6$ years $(6.66 \pm 4.39)$ and 6-10 years $(10.06 \pm 8.69)$.

Conclusions: Evaluation of hs-CRP concentrations irrespective of lipid status may serve as an inexpensive method of predicting the risk of development of diabetic complications in resource poor settings among patients with established type 1 diabetes as the duration progresses.

\section{Background}

Type 1 diabetes results from an autoimmune process that destroys insulin producing $B$ cells within the endocrine pancreatic islet [1] and represents approximately $10 \%$ of diabetes cases globally [2] with $<10 \%$ of affected patients presenting with idiopathic pathogenesis and no evidence of autoimmunity hence classified as type 1B [3]. C-reactive protein is a type I acute phase response protein synthesized in the liver or adipose tissue when tissue injury or microbial invasion occurs and is regulated by pro-inflammatory cytokines [4]. Elevated plasma level of CRP is a marker for endothelial cell dysfunction in uncomplicated, well-controlled type 1 diabetes and atherosclerosis through inflammatory pathways [5]. 
Effective insulin treatment improves lipid status and glycaemia in patients with type 1 diabetes [6, 7] However, in some patients elusive lipid abnormalities coexistent with hyperglycemia may accelerate vascular lesions [8] and metabolic crisis resulting from ketoacidosis [9].

The study was aimed at assessing the relationship between hs-CRP concentrations and duration of type 1 diabetes.

\section{Methods}

Thirty-four patients aged 15-26 years with duration of diabetes $\leq 10$ years comprising 20 males and 14 females resident in Jigawa State Nigeria diagnosed with ketoacidosis and no evidence of pancreatitis after a thorough medical history investigation and clinical examination at first presentation at the Accident and Emergency Unit, Rasheed Shekoni Specialist Hospital were enrolled for the study in a cross sectional pattern. During subsequent visitations to the Endocrinology Unit, Department of Medicine, Blood samples for lipid profile, fasting plasma glucose and hs-CRP level were collected from all patients after an overnight fast of 10 hours through venipuncture and transferred to appropriate specimen containers. Blood samples were centrifuged at $3000 \mathrm{rpm}$ for 5 minutes prior to biochemical testing. Serum hs-CRP concentration was assayed using ELISA technique (Monobind Inc, USA) while total cholesterol, high density lipoprotein-cholesterol, triglycerides and fasting plasma glucose were assayed using enzymatic methods (Agappe gmbh, Switzerland) on Selectra Pro S Chemistry analyzer (Elitech Systems). Urinalysis with point of care urine test strips (Combi 9, Medi- Test, Germany). Anthropometric parameters were measured and documented.

Urinalysis of patients at first presentation showed Urine Glucose; Positive 24(76.5\%), Negative 8(23.5\%), Urine Protein; Positive 4(11.8\%), Negative 30(88.2\%), Urine Ketones; Positive 4(11.8) Negative 30(88.2\%) and Fasting Plasma Glucose (mmol/l) $(21.52 \pm 5.45)$ and weight $(\mathrm{kg})$ at diagnosis $(45.06 \pm 14.67)$.

At subsequent visitation the biochemical analysis showed; Patients biochemical characteristics were Fasting Plasma Glucose $(9.86 \pm 4.44)$, Total Cholesterol (4.77 \pm 2.07$)$, High Density LipoproteinCholesterol (1.35 \pm 0.54$)$, Triglycerides ( $2.17 \pm 1.06)$, Low Density Lipoprotein- Cholesterol $(2.29 \pm 1.49)$, hs-CRP (6.99 \pm 5.44$)$. Anthropometric indices were Systolic Blood Pressure (108.8 \pm 12.50$)$, Diastolic Blood Pressure (71.76 \pm 12.67), Waist Circumference (Males: $71.50 \pm 8.20$, Females: $77.57 \pm 11.50$ ), Body Mass Index (Males: $17.24 \pm 3.35$, Females: $20.31 \pm 2.93$ ). Correlation matrix showed TG and hs-CRP (r; $\left.0.378^{\star *}, p ; 0.005\right)$, LDL-C and hs-CRP $(r ; 0.457 *, p ; 0.007)$. Mean hs- CRP concentrations in relation to duration of type 1 diabetes was $1-3$ years $(3.57 \pm 4.10), 3-6$ years $(6.66 \pm 4.39)$ and $6-10$ years $(10.06 \pm$ 8.69).

The data were analyzed using Statistical Package for Social Sciences (Version 25.0) Software. Qualitative variables are expressed as frequency and percentages while quantitative variables are presented as mean \pm standard deviation (SD). Correlation was performed using the Pearson's bivariate correlation. A p value was considered significant if less than 0.05 . Ethical approval for the study was 
obtained from the ethics and review committee of Rasheed Shekoni Specialist Hospital Dutse, Jigawa State Nigeria. Written informed consent was obtained from all participants prior to enrolment in the study.

\section{Results}

Table 1.0: Patients assessment at first clinical presentation

\begin{tabular}{|c|c|c|c|}
\hline Clinical assessment at $1^{\text {st }}$ Presentation & Rating & Frequency(n) & Percentage (\%) \\
\hline Urine Glucose & $\begin{array}{l}\text { Positive } \\
\text { Negative }\end{array}$ & $\begin{array}{c}24 \\
8\end{array}$ & $\begin{array}{l}76.5 \\
23.5\end{array}$ \\
\hline Urine Protein & $\begin{array}{l}\text { Positive } \\
\text { Negative }\end{array}$ & $\begin{array}{c}4 \\
30\end{array}$ & $\begin{array}{l}11.8 \\
88.2\end{array}$ \\
\hline Urine Ketones & $\begin{array}{l}\text { Positive } \\
\text { Negative }\end{array}$ & $\begin{array}{c}4 \\
30\end{array}$ & $\begin{array}{l}11.8 \\
88.2\end{array}$ \\
\hline Ketoacidosis & $\begin{array}{l}\text { None } \\
\text { Mild } \\
\text { Severe }\end{array}$ & $\begin{array}{c}2 \\
12 \\
20\end{array}$ & $\begin{array}{c}5.9 \\
35.3 \\
58.8\end{array}$ \\
\hline Polyuria & $\begin{array}{c}\text { None } \\
\text { Mild } \\
\text { Severe }\end{array}$ & $\begin{array}{c}0 \\
34 \\
0\end{array}$ & $\begin{array}{c}0 \\
100 \\
0\end{array}$ \\
\hline Polydipsia & $\begin{array}{l}\text { None } \\
\text { Mild } \\
\text { Severe }\end{array}$ & $\begin{array}{c}0 \\
34 \\
0\end{array}$ & $\begin{array}{c}0 \\
100 \\
0\end{array}$ \\
\hline Malnutrition & $\begin{array}{l}\text { None } \\
\text { Mild } \\
\text { Severe }\end{array}$ & $\begin{array}{c}18 \\
16 \\
0\end{array}$ & $\begin{array}{c}52.9 \\
47.1 \\
0\end{array}$ \\
\hline Weight loss & $\begin{array}{l}\text { None } \\
\text { Mild } \\
\text { Severe }\end{array}$ & $\begin{array}{c}2 \\
32 \\
0\end{array}$ & $\begin{array}{c}5.9 \\
94.1 \\
0\end{array}$ \\
\hline Blurred vision & $\begin{array}{l}\text { None } \\
\text { Mild } \\
\text { Severe }\end{array}$ & $\begin{array}{c}6 \\
28 \\
0\end{array}$ & $\begin{array}{c}17.6 \\
82.4 \\
0\end{array}$ \\
\hline Paresthesia & $\begin{array}{l}\text { Present } \\
\text { Absent }\end{array}$ & $\begin{array}{c}4 \\
30\end{array}$ & $\begin{array}{l}11.8 \\
88.2\end{array}$ \\
\hline Body swelling & $\begin{array}{l}\text { Present } \\
\text { Absent }\end{array}$ & $\begin{array}{l}20 \\
14\end{array}$ & $\begin{array}{l}58.8 \\
41.2\end{array}$ \\
\hline Frothy urine & $\begin{array}{l}\text { Present } \\
\text { Absent }\end{array}$ & $\begin{array}{l}12 \\
22 \\
\end{array}$ & $\begin{array}{l}35.3 \\
64.7 \\
\end{array}$ \\
\hline
\end{tabular}


Table 2.0: Biochemical and Anthropometric Characteristics of Patients at Subsequent Visitation

\begin{tabular}{|c|c|}
\hline Parameter & Mean \pm SD \\
\hline Fasting Plasma Glucose $(\mathrm{mmol} / \mathrm{l})$ & $9.85 \pm 4.44$ \\
\hline Total Cholesterol (mmol/l) & $4.77 \pm 2.07$ \\
\hline High Density Lipoprotein- Cholesterol (mmol/l) & $1.35 \pm 0.54$ \\
\hline Triglycerides (mmol/l) & $2.17 \pm 1.06$ \\
\hline Low Density Lipoprotein- Cholesterol (mmol/l) & $2.29 \pm 1.49$ \\
\hline High sensitivity C-reactive Protein $(\mu \mathrm{g} / \mathrm{ml})$ & $6.99 \pm 5.44$ \\
\hline Age (years) & $22.06 \pm 6.21$ \\
\hline Weight $(\mathrm{kg})$ & $48.29 \pm 2.40$ \\
\hline Height (cm) & $161 \pm 0.13$ \\
\hline Systolic Blood Pressure (mmHg) & $108.8 \pm 12.50$ \\
\hline Diastolic Blood Pressure (mmHg) & $71.76 \pm 12.67$ \\
\hline Waist Circumference $(\mathrm{cm})$-Males & $71.50 \pm 8.20$ \\
\hline Waist circumference $(\mathrm{cm})$-Females & $77.57 \pm 11.50$ \\
\hline Body Mass Index $\left(\mathrm{kg} / \mathrm{m}^{2}\right)$-Males & $17.24 \pm 3.35$ \\
\hline Body Mass Index $\left(\mathrm{kg} / \mathrm{m}^{2}\right)$-Females & $20.31 \pm 2.93$ \\
\hline
\end{tabular}


Table 3.0: Correlation between Biochemical Parameters

\begin{tabular}{llllllll}
\hline & & FPG & TC & HDL-C & TG & LDL-C & HS-CRP \\
\hline FPG $(\mathrm{mmol} / \mathrm{l})$ & $\mathrm{r}$ & & $-0.392^{*}$ & 0.252 & -0.243 & 0.221 & 0.015 \\
& $\mathrm{p}$ & & 0.022 & 0.150 & 0.167 & 0.208 & 0.935 \\
$\mathrm{TC}(\mathrm{mmol} / \mathrm{l})$ & $\mathrm{r}$ & $-0.392^{*}$ & & $0.351^{*}$ & $0.408^{*}$ & $0.932^{* *}$ & $0.466^{* *}$ \\
& $\mathrm{p}$ & 0.022 & & 0.038 & 0.016 & 0.000 & 0.005 \\
$\mathrm{HDL}-\mathrm{C}(\mathrm{mmol} / \mathrm{l})$ & $\mathrm{r}$ & 0.252 & $0.357^{* *}$ & & 0.139 & $0.375^{*}$ & 0.337 \\
& $\mathrm{p}$ & 0.150 & 0.038 & & 0.432 & 0.029 & 0.051 \\
$\mathrm{TG}(\mathrm{mmol} / \mathrm{l})$ & $\mathrm{r}$ & -0.243 & $0.408^{*}$ & 0.139 & & 0.210 & $0.378^{*}$ \\
& $\mathrm{p}$ & 0.167 & 0.016 & 0.432 & & 0.332 & 0.027 \\
$\mathrm{LDL}-\mathrm{C}(\mathrm{mmol} / \mathrm{l})$ & $\mathrm{r}$ & -0.221 & $0.932^{* *}$ & $0.375^{*}$ & 0.210 & & $0.457^{*}$ \\
& $\mathrm{p}$ & 0.208 & 0.000 & 0.029 & 0.232 & & 0.007 \\
$\mathrm{hs}-\mathrm{CRP}(\mu \mathrm{g} / \mathrm{ml})$ & $\mathrm{r}$ & 0.015 & $0.466^{* *}$ & 0.337 & $0.378^{*}$ & 0.457 & 0.007 \\
& $\mathrm{p}$ & 0.935 & 0.005 & 0.051 & 0.027 & & \\
\hline
\end{tabular}

FPG: Fasting Plasma Glucose, TC: Total Cholesterol, HDL-C: High Density Lipoprotein-Cholesterol, TG:

Triglycerides, LDL-C: Low Density Lipoprotein- Cholesterol, Hs-CRP: High Sensitivity C-reactive protein

${ }^{*}$ Correlation is significant at the 0.05 level (2-tailed)

${ }^{* *}$ Correlation is significant at the 0.01 level (2-tailed)

Table 4.0: Correlation between high sensitivity C- reactive protein with anthropometric

parameters

\begin{tabular}{|c|c|c|c|c|c|c|c|c|c|}
\hline & & Hs-CRP & Weight & Height & BMI & SBP & $\overline{\text { DBP }}$ & $\overline{W C}$ & Age \\
\hline \multirow[t]{2}{*}{ hs-CRP } & $\mathrm{r}$ & & 0.244 & $-0.428^{*}$ & 0.076 & 0.112 & -0.066 & -0.128 & -0.031 \\
\hline & $\mathrm{p}$ & & 0.165 & 0.012 & 0.671 & 0.528 & 0.711 & 0.472 & 0.860 \\
\hline \multirow[t]{2}{*}{ Weight } & $r$ & 0.244 & & 0.809 & $0.907 * *$ & $0.675^{* *}$ & $0.579 *$ & $0.790 * *$ & $0.648 * *$ \\
\hline & $\mathrm{p}$ & 0.165 & & 0.000 & 0.000 & 0.000 & 0.000 & 0.000 & 0.000 \\
\hline \multirow[t]{2}{*}{ Height } & $r$ & $-0.428^{*}$ & 0.809 & & $0.495^{* *}$ & $0.526 * *$ & $0.527 * *$ & $0.701^{* *}$ & $0.719^{* *}$ \\
\hline & $\mathrm{p}$ & 0.012 & 0.000 & & 0.003 & 0.001 & 0.001 & 0.000 & 0.000 \\
\hline \multirow[t]{2}{*}{ BMI } & $\mathrm{r}$ & -0.076 & $0.907^{* *}$ & $0.495^{* *}$ & & $0.661^{* *}$ & $0.539^{* *}$ & $0.640^{* *}$ & $0.451^{* *}$ \\
\hline & $\mathrm{p}$ & 0.671 & 0.000 & 0.003 & & 0.000 & 0.001 & 0.000 & 0.007 \\
\hline \multirow[t]{2}{*}{ SBP } & $\mathrm{r}$ & -0.112 & $0.675^{* *}$ & $0.526^{* *}$ & 0.661 & & $0.856^{* *}$ & $0.456^{* *}$ & $0.625^{* *}$ \\
\hline & $\mathrm{p}$ & 0.528 & 0.000 & 0.001 & 0.000 & & 0.000 & 0.007 & 0.000 \\
\hline \multirow[t]{2}{*}{ DBP } & $\mathrm{r}$ & -0.066 & $0.579^{* *}$ & $0.527^{* *}$ & $0.539^{* *}$ & $0.856^{* *}$ & & $0.392 *$ & $0.561^{* *}$ \\
\hline & $\mathrm{p}$ & 0.711 & 0.000 & 0.001 & 0.001 & 0.000 & & 0.022 & 0.001 \\
\hline \multirow[t]{2}{*}{ WC } & $\mathrm{r}$ & -0.128 & $0.790^{* *}$ & $0.701^{* *}$ & $0.640^{* *}$ & $0.456^{* *}$ & $0.392^{*}$ & & $0.525^{* *}$ \\
\hline & $\mathrm{p}$ & 0.472 & 0.000 & 0.000 & 0.000 & 0.007 & 0.022 & & 0.001 \\
\hline \multirow[t]{2}{*}{ Age } & $\mathrm{r}$ & -0.031 & $0.648^{* *}$ & $0.719^{* *}$ & $0.451^{* *}$ & $0.625^{*}$ & $0.561^{* *}$ & $0.525^{* *}$ & \\
\hline & $\mathrm{p}$ & 0.860 & 0.000 & 0.000 & 0.007 & 0.000 & 0.001 & 0.001 & \\
\hline
\end{tabular}

WC: Waist Circumference, SBP: Systolic Blood Pressure, DBP: Diastolic Blood Pressure, BMI: Body Mass Index, hs-CRP: high sensitivity $\mathrm{C}$ - reactive protein

${ }^{*}$ Correlation is significant at the 0.05 level (2-tailed)

** Correlation is significant at the 0.01 level (2-tailed) 
Table 5.0: Relationship between Duration of Diabetes and hs-CRP concentration

\begin{tabular}{cccc}
\hline $\begin{array}{c}\text { Duration of Diabetes } \\
\text { (years) }\end{array}$ & Hs-CRP $(\mu \mathrm{g} / \mathrm{ml})$ & Frequency $(\mathrm{n})$ & Percentage (\%) \\
\hline $1-3$ & $3.57 \pm 4.10$ & 4 & 11.8 \\
$3-6$ & $6.66 \pm 4.39$ & 24 & 70.6 \\
$6-10$ & $10.06 \pm 8.69$ & 6 & 17.6 \\
\hline
\end{tabular}

Hs-CRP: high sensitivity C-reactive protein

\section{Discussion}

Chronic inflammation characterized by elevated hs-CRP concentration has been reported to be associated with incident diabetes mellitus, hypertension and obesity [7]. Elevated hs-CRP concentration is independently linked with the development of type 1 diabetes $[9,16]$ and type 2 diabetes $[7,8]$. We observed an above normal limit FPG among the patients despite the intensive blood glucose monitoring and a negative correlation between hs-CRP levels and FPG in our study which is in concordance with the studies of $[5,6,11,12,13]$. Studies have also reported an elevation of HBA1c among patients with type 1 diabetes $[6,11,16]$ and type 2 diabetes $[9,12,20]$. Our inability to assay HbA1c might not give a true representation of glycemia which is a major limitation to our study.

Lipid profile among patients was within normal limits in our study. We observed a positive correlation between hs-CRP concentrations, triglycerides, TC and LDL-C as reported in studies [10-14]. This may be linked to the established association between systemic inflammation and lipid status in patients with diabetes and the fact that none of the patients recruited for our study was taking oral antihypertensive medication which is known to be associated with lower risk of obtaining elevated hs-CRP levels as reported by Svensson et al., 2014.

Body mass index correlated positively with age, systolic blood pressure, diastolic blood pressure and waist circumference. Our study showed increased BMI among patients which is similar to $[2,10,11,13$, $14,20]$ but contrary to the findings of [6]. Our study also observed that BMI and WC were elevated in females compared to males which are contrary to the reports of $[12,15]$.

Our study also found a positive correlation between BMI, SBP and DBP which is in concordance with the study of Kastelan et al., 2014. Although the study by Ladela et al., 2006 reported increased levels of BMI, SBP and DBP among subjects with type-1 diabetes in comparison to the controls, no correlation between the parameters was reported in the study.

Hs-CRP concentrations increased with prolonged duration of diabetes in our study which is in line with the studies of $[2,3,5,9,10,11]$ which reported a relationship between duration of diabetes, increased hs- 
CRP concentrations and resultant chronic inflammation. However, Wong et al., 2010 found a correlation between Hs-CRP levels and DOD in females only.

Our study observed a negative correlation between hs-CRP concentrations and the age of the patients which is contrary to the findings of $[4,10,14]$ who reported that young age was associated with substantially higher prevalence of CRP than old age. Although, none of the studies enrolled patients strictly diagnosed with type 1 diabetes.

Hs-CRP concentration correlated negatively with the waist circumference of the patients in our study which is dissimilar to the finding of Klisic et al., 2014. The absence of measurement of the hip circumference in our study did not provide the basis for calculating the WHR which several studies $[2,5,6$, 12] conducted employed. As a result, there was no room for comparison between our study and other studies.

The strength of our study lies in its ability to employ both retrospective and prospective data and the capacity to recruit patients with type 1 diabetes only.

The limitation of the study includes its inability to enroll control subjects for comparison of findings between the diabetic patients and apparently healthy individuals and the small sample size because type 1 diabetic patients represent a minority group of patients that present with diabetes mellitus at the endocrinology clinic.

Further studies are required to investigate the pathogenic role of hs-CRP in relation to systemic inflammation and duration of diabetes in patients with established type 1 diabetes.

Conclusion: Elevation in hs-CRP concentrations and irrespective of lipid status may serve as an inexpensive method of predicting and assessing the development of diabetic complications in resource poor settings. However, further studies are necessary to investigate the role of hs-CRP in relation to metabolic and clinical changes in patients with established type 1 diabetes mellitus as the duration progresses.

\section{Abbreviations}

hs-CRP

high sensitivity c-reactive protein

WHR

Waist to Hip Ratio

FPG

Fasting Plasma Glucose

LDL-C

Low Density Lipoprotein- Cholesterol

HbA1c 
Glycated Hemoglobin

TC

Total Cholesterol

HDL-C

High Density Lipoprotein-Cholesterol

TG

Triglycerides

BMI

Body Mass Index

SBP

Systolic Blood Pressure

DBP

Diastolic Blood Pressure

WC

Waist Circumference

DOD

Duration of Diabetes

\section{Declarations}

\section{ETHICS APPROVAL AND CONSENT TO PARTICIPATE}

Written informed consent was obtained from all participants prior to enrolment in the study. For the children under 16 years of age, written informed consent was obtained from parents and guardians before enrollment of the children into the study. The study was approved by the Ethical Committee of the Rasheed Shekoni Specialist Hospital Dutse Jigawa State. Ref: RSSH/GEN/226/V.1/36

CONSENT FOR PUBLICATION

Not Applicable

AVAILABILITY OF DATA AND MATERIALS

The datasets used and or analyzed during the current study are available from the corresponding author on reasonable request.

COMPETING INTEREST

The authors declare that they have no competing interests.

FUNDING

No Source of funding was obtained for the study 
$\mathrm{BH}, \mathrm{MSB}, \mathrm{AMB}$ and GYM were the principal investigators, conceptualized and organized the study. MSB, MA and IDG assisted with patient recruitment, data collection and analysis. $\mathrm{BH}$ and MSB were the principal medical statisticians for data processing, statistical analysis and critical review of the manuscript. All authors read and approved the final manuscript.

\section{ACKNOWLEDGEMENTS}

Not Applicable

\section{References}

1. Narendran P, Estella E, Fourlanos S. Immunology of type 1 diabetes. QJM 2005; 98: 547-56.

2. Paschou SA, Papadopoulou-Marketou N, Chrousos GP, Kanaka-Gantenbein C. On type 1 diabetes mellitus pathogenesis. Endocrine Connections. 2018; 7(1): R38-R46.

3. Paschou SA, Petsiou A, Chatzigianni K, Tsatsoulis A. Papadopoulos GK. Type 1 diabetes as an autoimmune disease: the evidence. Diabetologia. 2014; 57:1500-1501.

4. Abdo $\mathrm{M}$, Elsaid $\mathrm{HH}$, Plasma high sensitivity C-reactive protein as a marker of severity in children with diabetic ketoacidosis. Egypt J Pediatric Allergy Immunol. 2014; 12(1): 37-41.

5. Colhoun HM, Schalkwijk C, Rubens MB, Stehouwer CDA. C - reactive protein in type 1 diabetes and its relationship to coronary artery calcification. Diabetes Care. 2002; 25:1813-1817.

6. Machnica L, Deja G, Polanska J, and Jarosz-Chobot P. Blood pressure disturbances and endothelial dysfunction markers in children and adolescents with type 1 diabetes. Atherosclerosis. 2014; 237(1):129-134.

7. Feitosa ACR, Feitosa-Filho GS, Freitas FR, Wajchenberg BL, Maranhão RC. Lipoprotein metabolism in patients with type 1 diabetes under intensive insulin treatment. Lipids in Health and Disease. 2013; $12: 15$.

8. Zachurzok A, Deja G, Gawlik A, Drosdzol-Cop A, Klimek K, and Malecka-Tendera E. Lipid Profile in Adolescent Girls with Type 1 Diabetes Mellitus and Hyperandrogenemia. International Journal of Endocrinology. 2016; http://dx.doi.org/10.1155/2016/9473158.

9. Guy J, Ogden L, Wadwa RP, Hamman RF, Mayer-Davis EJ, Liese AD, Jr D’Agostino R, Marcovina S, Dabelea D: Lipid and lipoprotein profiles in youth with and without type 1 diabetes: the SEARCH for Diabetes in Youth case-control study. Diabetes Care. 2009; 32:416-420.

10. Kanmani S, Kwon M, Shin M-K, Kim MK. Association of C-Reactive protein with Risk of Developing Type 2 Diabetes Mellitus, and Role of Obesity and Hypertension: A Large Population-Based Korean Cohort Study. Scientific Reports. 2019; 9:4573.

11. Doi Y, Kiyohara Y, Kubo M, Tanizaki Y, Okubo K, Ninomiya T, Iwase M, lida M. Relationship Between CReactive Protein and Glucose Levels in Community- Dwelling Subjects Without Diabetes The 
Hisayama Study. Diabetes Care. 2005; 28(5): 1211-1213.

12. King DE, lii AGM, Buchanan TA, Pearson WS. C - reactive protein and Glycemic Control in Adults with Diabetes. Diabetes Care. 2003; 26:1535-1539.

13. Lim LS, Tai ES, Mitchell P, Wang J, Tay WT, Lamoureux E and Wong TY. C - reactive protein, Body Mass Index, and Diabetic Retinopathy. Clinical and Epidemiologic Research. 2010; 51(9):4458-4463.

14. Dongway AC, Faggad AG, Zaki HY, Abdalla BE. C-reactive protein is associated with low-density lipoprotein cholesterol and obesity in type 2 diabetic Sudanese. Diabetes, Metabolic Syndrome and Obesity: Targets and Therapy. 2015; (8):427-435.

15. Ladeia AM, Stefanelli E, Ladeia-Frota C, Moreira A, Hiltner A, Adan L. Association Between Elevated Serum $C$ - reactive protein and Triglyceride Levels in Young Subjects with Type 1 Diabetes. Diabetes Care. 2006; 29(2):424-426.

16. Bandyopadhyay R, Paul R, Basu AK, Chakraborty PP, Mitra S. Study of C Reactive Protein in Type 2 Diabetes and its Relation with Various Complications from Eastern India. Journal of Applied Pharmaceutical Science. 2013;3(7):156-159.

17. Chianeh YR, Prabhu K, Bhat VR, Udupa P, Bagheri A, Baliga S, Chelikani RT. High-sensitive C-reactive protein levels in diabetes associated with Dyslipidemia. National Journal of Physiology, Pharmacy and Pharmacology. 2016; 6(5):480-483.

18. Klisic AN, Vasiljevic ND, Simic TP, Djukic TI, Maksimovic MZ, Matic MG. Association between C reactive protein, Anthropometric and Lipid Parameters Among Healthy Normal Weight and Overweight Postmenopausal Women in Montenegro. Laboratory Medicine. 2014; 45(1):12-16.

19. Channanath AM, Elkum N, Al-Abdulrazzaq D, Tuomilehto J, Shaltout A, Thanaraj TA. Ethnic differences in association of high body mass index with early onset of Type 1 diabetes \pm Arab ethnicity as case study. PLoS ONE. 2017; 12(4):e0175728.1-13.

20. Kaštelan SD, RabatiT JS, TomiT M, Antunica AG, jubiT S, Kaštelan H, Novak B and OreškoviT D. Body Mass Index and Retinopathy in Type 1 Diabetic Patients. International Journal of Endocrinology. 2014; http://dx.doi.org/10.1155/2014/387919. 